Case Report

\title{
Adult T-cell leukemia/lymphoma triggered by adalimumab
}

\author{
Achilea L Bittencourt ${ }^{\mathrm{a}}$, Pedro D Oliveira ${ }^{\mathrm{b}}$, Valeria G Bittencourt ${ }^{\mathrm{c}}$, Edgar M Carvalho ${ }^{\mathrm{c}}$, \\ Lourdes Farre $^{\mathrm{d}, *}$ \\ a Laboratory of Pathology. Complexo Hospitalar Universitário Prof. Edgard Santos, Federal University of Bahia, Rua Dr. Augusto Viana, s/n, Canela, \\ CEP:40.110-060, Salvador, Bahia, Brazil \\ ${ }^{\mathrm{b}}$ Dermatology Service. Complexo Hospitalar Universitário Prof. Edgard Santos, Federal University of Bahia, Rua Dr. Augusto Viana, s/n, Canela, \\ CEP:40.110-060, Salvador, Bahia, Brazil \\ ${ }^{\mathrm{c}}$ Laboratory of Immunology. Complexo Hospitalar Universitário Prof. Edgard Santos, Federal University of Bahia, Rua Dr. Augusto Viana, s/n, Canela, \\ CEP:40.110-060, Salvador, Bahia, Brazil \\ d Laboratory of Experimental Pathology (LAPEX), CPQGM-FIOCRUZ, Bahia, Rua Waldemar Falcão 121, Candeal, CEP: 40296-710, Salvador, Bahia, Brazil
}

\section{A R T I C L E I N F O}

\section{Article history:}

Received 14 May 2013

Received in revised form 12 July 2013

Accepted 15 July 2013

\section{Keywords:}

Adult T-cell leukemia/lymphoma

Infective dermatitis associated with HTLV-1

Adalimumab

Anti-TNF- $\alpha$ drugs

\begin{abstract}
A B S T R A C T
Here, we describe a 48-year-old woman infected by the human T-cell lymphotropic virus type 1 (HTLV1) with spondyloarthritis, uveitis, bilateral episcleritis and neurogenic bladder. She had a history of a probable infective dermatitis associated with HTLV-1 (IDH) in childhood. After the use of adalimumab, she developed lymphocytosis and a cutaneous lymphoma associated with IDH. She had the diagnoses of IDH and of chronic adult T-cell leukemia/lymphoma, supported by the demonstration of proviral integration in the cutaneous lesion.
\end{abstract}

(c) 2013 Elsevier B.V. All rights reserved.

\section{Why this case is important}

Rare cases with infective dermatitis associated with HTLV1 (IDH) have been described associated with adult T-cell leukemia/lymphoma [1]. Here, we describe a case with both diseases triggered by the administration of adalimumab.

\section{Case report}

The patient was a 48-year-old afrodescendent woman, from Salvador, Bahia, with positive serology for the human T-cell lymphotropic virus type 1 (HTLV-1) who had the following diagnoses at the Universitary Hospital of the Federal University of Bahia: spondyloarthritis, uveitis, bilateral episcleritis, and neurogenic bladder. She also had a history of a severe eczema in childhood involving the scalp, the retroauricular areas and the cutaneous folds.

Due to the worsening of the rheumatological clinical picture and poor response to oral immunosuppressants, an anti-TNF$\alpha$ (adalimumab) was introduced. After this treatment the

\footnotetext{
* Corresponding author at: Laboratory of Pathology. Complexo Hospitalar Universitário Prof. Edgard Santos, Federal University of Bahia, Rua Dr. Augusto Viana, s/n, Canela, CEP:40.110-060, Salvador, Bahia, Brazil. Tel.: +557132838016.

E-mail address: achilea@uol.com.br (L. Farre).
}

patient progressed with persistent discrete lymphocytosis (5.049 to 5.882 cells $/ \mu \mathrm{L}$ ) and 27 months later, showed erythematous papules on the limbs, back and breasts (Fig. 1A). Simultaneously erythematous-scaly lesions appeared on the scalp, retroauricular regions, posterior aspect of the neck (Fig. 1B), inframammary folds (Fig. 1A) and axillae associated with numerous follicular papules on the abdomen. At that time, laboratory examinations revealed lymphocytosis ( 5.168 cells $/ \mu \mathrm{L}$ ), mild elevated serum lactate dehydrogenase and normal blood calcium level. No infiltration was observed in the biopsy of the bone marrow.

Histopathological examination of a papular lesion showed a pagetoid epidermotropism and patchy areas of dense infiltration of small and medium atypical cells, in the superficial and mid dermis (Figs. 1C and D) showing a classic mycosis fungoides (MF) pattern. By immunohistochemistry the atypical cells were $\mathrm{CD}^{+}$, $\mathrm{CD}^{+}, \mathrm{CD}^{-}, \mathrm{CD}^{-} 0^{-}, \mathrm{CD} 25^{+}, \mathrm{CD} 30^{-}$and $\mathrm{CD} 68^{-}$. The proliferative index assessed by Ki-67 was $8 \%$. Monoclonal integration of HTLV-1 was detected by Southern blot [2] in the skin lesion (Fig. 2). Complete staging showed no involvement of other organs. Chronic adult T-cell leukemia/lymphoma (ATL) was diagnosed according to the Shimoyama's classification (1991) [3].

Adalimumab was suspended right after the diagnosis of MF and treatment with phototherapy and topical corticosteroids was initiated, without response. Right after, specific treatment for ATL with interferon- $\alpha$ in combination with zidovudine was introduced with complete disappearance of the skin lesions and lymphocytosis. 


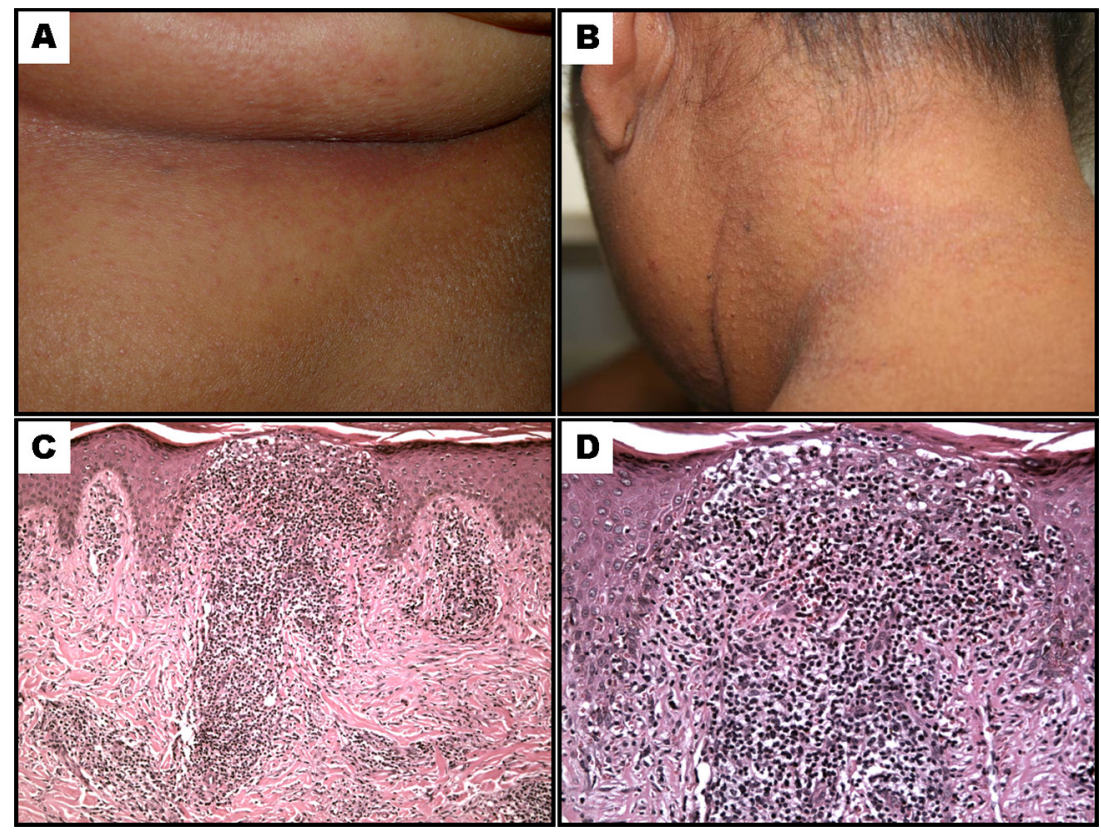

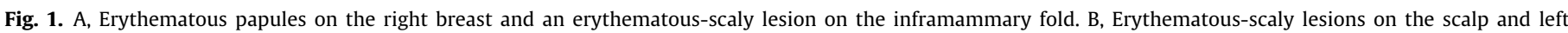

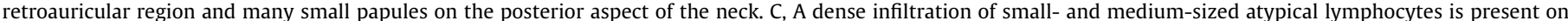

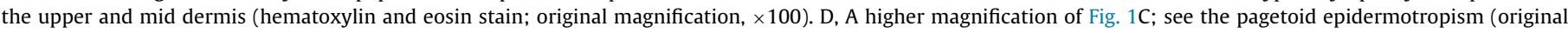
magnification, $\mathrm{x} 200$ ).

Now, after 16 months of treatment, autoimmune diseases are under control.

\section{Other similar and contrasting cases in the literature}

There are no other reports about the development of ATL due to anti-TNF- $\alpha$ treatment. The association of ATL, IDH and HTLV-1

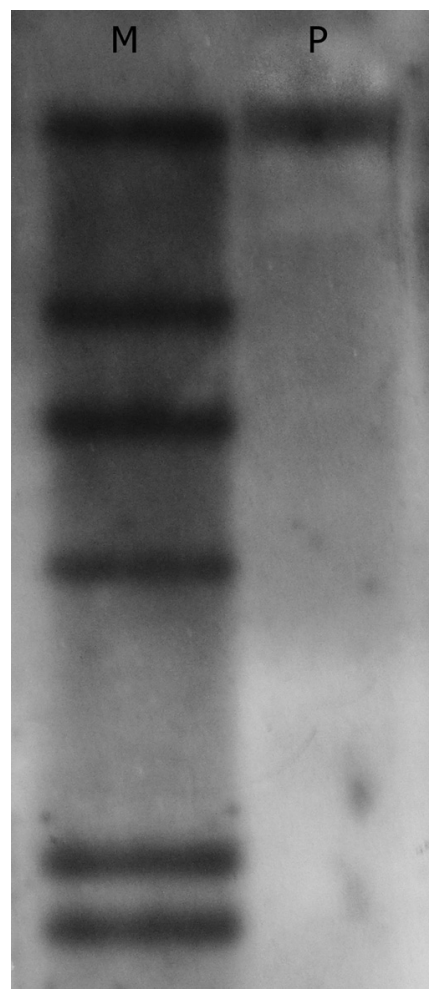

Fig. 2. Polyacrylamide gel of long, inverted PCR products. Lane M, DNA molecular weight marker VIII (Roche); lane P, patient with adult T-cell leucemia/lymphoma. associated myelopathy/tropical spastic paraparesis (HAM/TSP) has been previously described [1].

\section{Discussion}

Infection by the HTLV-1 causes several diseases, among them ATL, HAM/TSP, infective dermatitis associated with HTLV-1 (IDH), and is associated with autoimmune diseases such as rheumatoid arthritis, uveitis, and spondyloarthritis [4]. There have been no reports of ATL induction by anti-TNF- $\alpha$, but TNF- $\alpha$ inhibitors have been associated with the development of lymphomas and, in particular, T-cell lymphomas [5].

This is an uncommon case, due to the combination of several diseases caused by HTLV-1. The ATL lesions appeared concomitantly with a classic pattern of IDH with lesions in the scalp, retroauricular regions and folds [6]. The presence of a neurogenic bladder probably corresponded to an initial form of HAM/TSP [7]. The combination of HAM/TSP and ATL, although considered rare [8], has been commonly observed in Bahia, Brazil, where $19 \%$ of the cases of ATL with skin involvement have shown this combination [9]. Even more rare was the association of ATL and HAM/TSP with other HTLV-1 associated diseases, such as IDH [1] and uveites [10].

Monoclonal viral integration has shown, without a doubt, that it was, in fact, ATL [11]. The presence of lymphocytosis and cutaneous lymphoma, even in the absence of other involvements, led to the diagnosis of chronic ATL. This lymphoma may mimick, histologically, several others lymphomas, including MF [9].

TNF- $\alpha$ pharmacological blockage has been shown to be effective in the treatment of several immunologically mediated diseases, which is why it was used with this patient. However, TNF- $\alpha$ blockers are markedly immunosuppressant, and may even result in the reactivation of infectious diseases $[12,13]$ and B and T-cell lymphomas [14]. In an FDA database, 100 T-cell lymphomas were identified in patients treated only with anti-TNF- $\alpha$, with 20 showing MF/Sezary syndrome (SS). In a literature review, 10 other cases of MF/SS treated in this way have also been observed [5]. However, no reference was found in the literature of the development 
of ATL due to anti-TNF- $\alpha$ treatment. Considering that the patient had had a history of a severe eczema in childhood, certainly the anti-TNF- $\alpha$ also caused a reappearance of the IDH. It is possible that the marked suppression of cellular immune response through medication may have permitted the proliferation of a transformed T-cell clone causing ATL.

\section{Funding}

None.

\section{Competing interests}

None.

\section{Ethical approval}

Not required.

\section{Disclosure}

The authors have nothing to disclose.

\section{Acknowledgements}

This work was supported in part by Conselho Nacional de Pesquisa and Fundação de Amparo à Pesquisa do Estado da Bahia.

\section{References}

[1] Farré L, Bittencourt AL, Oliveira MFSP, et al. Early sequential development of infective dermatitis, human T-Cell lymphotropic virus type I (HTLV-1)associated myelopathy and adult T-Cell leukemia/lymphoma. Clin Infect Dis 2008;46:440-2.
[2] Kamihira S, Sugahara K, Tsuruda K, et al. Proviral status of HTLV-1 integrated into the host genomic DNA of adult T-cell leukemia cells. Clin Lab Haematol 2005;27:235-41.

[3] Shimoyama M. Diagnostic criteria and classification of clinical subtypes of adult T-cell leukaemia-lymphoma. A report from the lymphoma study group (198487). Br J Haematol 1991;79:428-37.

[4] Goncalves DU, Proietti FA, Ribas JG, et al. Epidemiology, treatment, and preven tion of human T-cell leukemia virus type 1-associated diseases. Clin Microbiol Rev 2010;23:577-89.

[5] Deepak P, Sifuentes H, Sherid M, et al. T-cell non-Hodgkin's lymphomas reported to the FDA AERS with tumor necrosis factor-alpha (TNF- $\alpha$ ) inhibitors: results of the REFURBISH study. Am J Gastroenterol 2013;108: 99-105.

[6] Oliveira MF, Fatal PL, Primo JR, et al. Infective dermatitis associated with human T-cell lymphotropic virus type 1: evaluation of 42 cases observed in Bahia, Brazil. Clin Infect Dis 2012;54:1714-9.

[7] Santos SB, Oliveira P, Luna T, et al. Immunological and viral features in patients with overactive bladder associated with human T-cell lymphotropic virus type 1 infection. J Med Virol 2012;84:1809-17.

[8] Tamiya S, Matsuoka M, Takemoto S, et al. Adult T cell leukemia following HTLV-I-associated myelopathy/tropical spastic paraparesis: case reports and implication to the natural course of ATL. Leukemia 1995;9:1768-70.

[9] Bittencourt AL, Barbosa HS, Vieira MD, et al. Adult T-cell leukemia/lymphoma (ATL) presenting in the skin: clinical, histological and immunohis tochemical features of 52 cases. Acta Oncol (Stockholm) 2009;48: 598-604.

[10] Gonçalves DU, Guedes AC, Carneiro-Proietti AB, et al. Simultaneous occurrence of HTLV-I associated myelopathy, uveitis and smouldering adult T cell leukaemia, GIPH (Interdisciplinary HTLV-I/II Research Group). Int J STD AIDS 1999;10:336-7.

[11] Tsukasaki K, Hermine O, Bazarbachi A, et al. Definition, prognostic factors, treatment, and response criteria of adult T-cell leukemia-lymphoma: a proposal from an international consensus meeting. J Clin Oncol 2009;27: 453-9.

[12] Keane J, Gershon H, Pharm D, Wise RP, et al. Tuberculosis associated with infliximab, a tumor necrosis factor $a$-neutralizing agent. N Engl J Med 2001;345:1098-104.

[13] Suga H, Sugaya M, Tamaki Z, Yamamoto M, Tada Y, Sato S. Varicella-like generalized pustulosis induced by adalimumab. Int J Dermatol 2013;52: 890-2.

[14] Adams AE, Zwicker J, Curiel C, et al. Aggressive cutaneous T-cell lymphomas after TNF-alpha blockade. J Am Acad Dermatol 2004;51:660-2. 